\title{
TOMATO INFRARED DRYING: MODELING AND SOME COEFFICIENTS OF THE DEHYDRATION PROCESS
}

\author{
Paulo Cesar Corrêa ${ }^{1}$, Gabriel Henrique Horta de Oliveira ${ }^{2 *}$, Fernanda Machado Baptestini ${ }^{1}$, \\ Mayra Darliane Martins Silva Diniz ${ }^{1}$, and Aline Almeida da Paixão ${ }^{1}$
}

Infrared dehydration is more advantageous than the convective system under similar conditions, and studying this process is important to further develop equipment and procedures. Thus, the aim of this work was to study the dehydration process of tomato (Solanum lycopersicum L.) slices obtained by infrared drying at three different maturity stages throughout two different procedures: Firstly, the drying model was determined by applying the mass and energy balances under wet bulb temperature for the constant drying rate period and secondly, the mass effective diffusion coefficient was determined throughout the experimental data and the theory of diffusion of the liquid phase for the decreasing drying rate period. Tomato fruits cv. Santa Cruz were used. Three maturity stages were selected: green (stage 1), orange (stage 2), and red (stage 3). Mathematical models frequently used to represent drying of agricultural products were fitted to the experimental data of tomato drying. The effective diffusion coefficient was obtained by adjusting the liquid diffusion mathematical model to the experimental data of the descending period of dehydration. The two-term model was the best one to represent the tomato dehydration process. The critical moisture content for tomato dehydration was $2.97 \mathrm{~kg}_{\mathrm{w}} \mathrm{kg}_{\mathrm{dm}}{ }^{-1}$. There is an initial dehydration period in which the drying rate reaches its maximum (approximately $1.05 \mathrm{~kg}_{\mathrm{w}} \mathrm{kg}_{\mathrm{dm}}{ }^{-1}$, about 3 min). Three different methods were used to obtain values of the effective diffusion coefficient, including the finite element method, which had the lowest values for the least square sum of deviation $1.00 \times 10^{-7} \mathrm{~m}^{2} \mathrm{~s}^{-1}$. The global coefficient of heat transfer was $12.45 \mathrm{~W} \mathrm{~m}^{-2} \mathrm{~K}^{-1}$, and the global coefficient of mass transfer was $0.0105 \mathrm{~m} \mathrm{~s}^{-1}$.

Key words: Critical moisture content, diffusion, finite element method, heat and mass transfer, mathematical modeling, Solanum lycopersicum.

$\mathrm{T}$ omato (Solanum lycopersicum L.) is one of the vegetables most consumed in the world. It is a source of vitamins $\mathrm{A}$ and $\mathrm{C}$ and mineral salts, such as $\mathrm{K}$ and $\mathrm{Mg}$. Tomato is a climacteric fruit with a short maturation and color change period, firmness, aroma, and flavor throughout shelf-life (Oliveira, 2010).

Dehydration has recently been used to increase shelflife of several fruits and vegetables (Vasques et al., 2006). Conservation through dehydration is based on the fact that microorganisms, enzymes, and the entire metabolic system of biological materials require water for their activities. A reduced amount of water decreases water activity and chemical reactions within the product, as well as the development of microorganisms (Christensen and Kaufmann, 1974). Therefore, the main objective of drying is reducing moisture content and water activity (Doymaz, 2005a; Corrêa et al., 2010a; Oliveira et al., 2010) since these parameters control product respiration rate and

${ }^{1}$ Universidade Federal de Viçosa, Agricultural Engineering Department, Campus UFV, Av. PH Rolfs, śn, 36570-000, Viçosa Minas Gerais, Brazil.

${ }^{2}$ Instituto Federal de Brasília, Campus Gama, Praça 2, śn, 72405980, Brasília-DF, Brazil.

"Corresponding author (gabriel.oliveira@ifb.edu.br).

Received: 5 August 2011.

Accepted: 18 May 2012. incidence of microorganisms and insects (Corrêa et al., 2010b; Goneli et al., 2010a; 2010b).

Infrared dehydration is more advantageous than the convective system under similar conditions (Sharma et al., 2005). When infrared is used to warm up or dehydrate wet materials, radiation encounters the exposed product, penetrates it, and radiation energy is converted into heat. The penetration depth of radiation depends on the material's properties and the radiation wavelength. When the product is exposed to radiation, it is intensively heated and the temperature gradient within the product is reduced in a short period of time.

Depending on the material to be dried, water can move through its interior by different mechanisms. In hygroscopic capillary-porous products, such as most agricultural products, the possible mechanisms of moisture movement are liquid diffusion, capillary diffusion, surface diffusion, hydrodynamic flow, vapor diffusion, and thermal diffusion (Brooker et al., 1992). The effective diffusion coefficient has been studied by different researchers in different products (Campos et al., 2009; Corrêa et al., 2010c); this parameter illustrates the moisture movement, intrinsic to the product, towards the outside due to drying.

Heat and mass transfer is intrinsically involved in reducing grain moisture (Hall, 1980) by drying. 
Simulating the behavior of each product during dehydration is an important parameter to develop and maximize grain drying equipment (Sacilik et al., 2006; Corrêa et al., 2010c), as well as selecting mathematical models that will represent moisture loss during drying. Moreover, transport phenomena of food and other important biological materials is a significant link between the processing of these materials and product quality and safety (Welti-Chanes et al., 2005).

Given the importance of studies on drying, the objective of this study was to model the dehydration process of tomato fruits at three different maturity stages, and also obtain the effective diffusion coefficient and global values of heat and mass transfer.

\section{MATERIALS AND METHODS}

The present work was conducted in the Laboratory of Physical Properties and Quality Evaluation of Agricultural Products at the National Grain Storage Training Center - CENTREINAR, Federal University of Viçosa, Viçosa, Minas Gerais, Brazil.

Tomato fruits cv. Santa Cruz were acquired at the local market. Three maturity stages were selected: green (stage 1 ), orange (stage 2 ), and red (stage 3 ). Each maturity stage had five replicates. Tomatoes were sliced approximately $5 \mathrm{~mm}$ thick and weighed on a digital scale with $0.001 \mathrm{~g}$ precision.

The study used a dryer with an infrared radiation source (model IV 2500, Gehaka, São Paulo, Brazil) for dehydration. This equipment contains a scale with 0.001 $\mathrm{g}$ precision and an automatic data acquisition system. The radiation source is located at a fixed distance of 15 $\mathrm{mm}$ from the product with an infrared power of $300 \mathrm{~W}$. Dehydration was carried out at $60{ }^{\circ} \mathrm{C}$. The moisture ratio of the tomato during drying was obtained by Equation [1]:

$$
M R=\frac{U_{t}^{*}-U_{e}^{*}}{U_{i}^{*}-U_{e}^{*}}
$$

where MR is the moisture ratio of the product, dimensionless; $U_{t}^{*}$ is the moisture content of the product at a certain drying time, decimal d.b.; $U_{i}^{*}$ is the initial moisture content of the product, decimal d.b.; and $U_{e}{ }^{*}$ is the equilibrium moisture content of the product, decimal d.b.

The mathematical models frequently applied to represent drying of agricultural products were fitted to the experimental data of tomato drying. These models are shown in Table 1.

The goodness of fit of the mathematical models was analyzed through non-linear regression and the Gauss Newton method with Statistica 8.0 (StatSoft, Tulsa, Oklahoma, USA). The fitness degree of each model was based on the determination coefficient $\left(\mathrm{R}^{2}\right)$, mean relative percent deviation $(\mathrm{P})$, and standard error (SE). The values of $\mathrm{P}$ and $\mathrm{SE}$ for each model were calculated by Equations [2] and [3]:
Table 1. Mathematical models used to represent the drying phenomenon of tomato.

\begin{tabular}{|c|c|c|}
\hline Model name & Model & Equation \\
\hline $\begin{array}{l}\text { Diffusion approximation } \\
\text { (Yaldiz and Ertekin, 2001) }\end{array}$ & $M R=a \exp (-k t)+(1-a) \exp (-k b t)$ & {$[2]$} \\
\hline Two-term (Henderson, 1974) & $M R=a \exp (-k t)+b \exp (-g t)$ & {$[3]$} \\
\hline $\begin{array}{l}\text { Henderson and Pabis } \\
\text { (Henderson and Pabis, 1961) }\end{array}$ & $M R=a \exp (-k t)$ & [4] \\
\hline Midilli (Midilli et al., 2002) & $M R=a \exp \left(-k t^{n}\right)+b t$ & {$[5]$} \\
\hline $\begin{array}{l}\text { Logarithmic } \\
\text { (Yagcioglu et al., 1999) }\end{array}$ & $M R=a \exp (-k t)+b$ & [6] \\
\hline Verma (Verma et al., 1985) & $M R=a \exp (-k t)+(1-a) \exp (-g t)$ & [7] \\
\hline $\begin{array}{l}\text { Page (Diamente and } \\
\text { Munro, 1993) }\end{array}$ & $M R=\exp \left(-k t^{n}\right)$ & [8] \\
\hline \multicolumn{3}{|c|}{$\begin{array}{l}\text { MR: moisture ratio, dimensionless; a, b, g, n: model parameters, dimensionless; k: drying } \\
\text { rate, } \mathrm{s}^{-1} ; \text { t: drying time, } \mathrm{s} \text {. }\end{array}$} \\
\hline & $=\frac{100}{n} \sum \frac{|Y-\hat{Y}|}{Y}$ & {$[2]$} \\
\hline
\end{tabular}

where $P$ is the mean relative percent deviation (\%); SE is the standard error, decimal d.b.; $Y$ is the observed value, dimensionless; $\hat{Y}$ is the value estimated by the model, dimensionless; $n$ is the number of observed data; and $\mathrm{DF}$ is the degrees of freedom of the model (number of observed data minus the number of model parameters).

The theories that govern the constant rate period of dehydration of agricultural products, according to Brooker et al. (1992), can be approximated to the heat and mass transfer balance studies for wet bulb temperature. Thus, the constant rate of dehydration can be represented by Equation [4]:

$$
\frac{d M}{d t}=\frac{h_{c} A}{L}\left(T_{\infty}-T_{b u}\right)=\frac{h_{m} A}{R_{v}}\left(\frac{P_{v b u}}{T_{b u}}-\frac{P_{b_{\infty}}}{T_{\infty}}\right)
$$

where $h_{c}$ is the global coefficient of heat transfer (W $\left.\mathrm{m}^{-2} \mathrm{~K}^{-1}\right) ; h_{m}$ is the global coefficient of mass transfer (m $\left.\mathrm{s}^{-1}\right) ; L$ is the latent heat of vaporization $\left(\mathrm{J} \mathrm{kg}^{-1}\right) ; R_{v}$ is the universal constant of water vapor $\left(461.91 \mathrm{~J} \mathrm{~kg}^{-1} \mathrm{~K}^{-1}\right)$; $A$ is the superficial area of tomato slices $\left(\mathrm{m}^{2}\right) ; P_{v b u}$ is the vapor pressure for the wet bulb temperature $(\mathrm{Pa}) ; P_{v \infty}$ is the vapor pressure for dehydration temperature $(\mathrm{Pa}) ; T_{b u}$ is the wet bulb temperature $(\mathrm{K}) ; T_{\infty}$ is the dehydration temperature $(\mathrm{K})$; and $d M / d t$ is the constant rate of dehydration $\left(\mathrm{kg} \mathrm{s}^{-1}\right)$.

Coefficients were calculated with the following parameters: plate geometric shape type, isothermal process, and neglecting volumetric shrinkage of the product.

The effective diffusion coefficient was obtained by adjusting the liquid diffusion mathematical model (Equation [5]) to the experimental data of the descending period of dehydration. This equation is the analytical solution of Fick's second law when considering the parameters of Equation [4]:

$$
M R=\frac{8}{\pi^{2}} \sum_{n=0}^{\infty} \frac{1}{(2 n+1)^{2}} \exp \left[-\frac{(2 n+1)^{2} \pi^{2} D_{e f t}}{4 L^{2}}\right]
$$


where $L$ is the half thickness of the slab $(\mathrm{m}) ; D_{\text {ef }}$ is the effective diffusion coefficient $\left(\mathrm{m}^{2} \mathrm{~s}^{-1}\right)$; and $n$ is the number of equation parameters.

\section{RESULTS AND DISCUSSION}

\section{Infrared dehydration modeling}

Table 2 shows the values of $\mathrm{P}, \mathrm{SE}$, and $\mathrm{R}^{2}$ for each model considered in the present study (Table 1) for tomato fruit drying.

Determining the coefficient $\left(\mathrm{R}^{2}\right)$ for non-linear models is not a good decision-making tool. It is necessary to analyze different statistical parameters. Thus, for model adequacy in describing a phenomenon, $\mathrm{P}$ values must be taken into consideration; the lowest values of $\mathrm{P}$ indicate a higher representation of the model for the phenomenon under study. Analyzing SE also helps to select models. Lower $\mathrm{SE}$ values indicate higher model reliability. Therefore, by analyzing these three statistical parameters shown in Table 2 , it was concluded that the two-term model is the best one to represent infrared drying of tomato fruit.

No significant difference was observed among tomato maturity stages at a $5 \%$ probability level by the Tukey test. As a result, Figure 1 represents the tomato drying curve. This figure shows the drying values observed and estimated by the two-term model at maturity stage 1. By analyzing Figure 1, the good adjustment of the two-term model to the experimental data can be observed, which satisfactorily represents tomato drying kinetics.

Thus, it is possible to estimate the moisture content of tomato during infrared drying at $60^{\circ} \mathrm{C}$ by Equation [6]:

$\mathrm{MR}=0.8952 \exp \left(-0.1036_{t}\right)+0.1503 \exp \left(-0.0064_{t}\right) \quad$ [6]

Figure 1 shows that some linearity occurs at approximately $10 \mathrm{~min}$ after the moisture ratio is reduced followed by an exponential reduction. The critical

Table 2. Mean relative percent deviation (P), standard error (SE), and determination coefficient $\left(R^{2}\right)$ for each mathematical model studied at 60 ${ }^{\circ} \mathrm{C}$ at each maturity stage.

\begin{tabular}{llrrr}
\hline $\begin{array}{l}\text { Maturity } \\
\text { stage }\end{array}$ & \multicolumn{1}{c}{ Model name } & $\mathrm{R}^{2}(\%)$ & $\mathrm{P}(\%)$ & $\begin{array}{c}\text { SE } \\
\text { (decimal } \\
\text { d.b. })\end{array}$ \\
\hline $1^{\text {st }}$ & Diffusion approximation & 98.50 & 9.30 & 0.03 \\
& Two-term & 98.69 & 9.05 & 0.03 \\
& Henderson and Pabis & 96.36 & 19.23 & 0.05 \\
& Logarithmic & 98.68 & 9.31 & 0.03 \\
& Midilli & 98.59 & 9.79 & 0.03 \\
& Page & 97.40 & 13.79 & 0.04 \\
& Verma & 98.49 & 9.30 & 0.03 \\
\hline $2^{\text {nd }}$ & Diffusion approximation & 95.66 & 13.93 & 0.05 \\
& Two-term & 95.85 & 13.81 & 0.05 \\
& Henderson and Pabis & 92.61 & 26.00 & 0.07 \\
& Logarithmic & 95.84 & 13.86 & 0.05 \\
& Midilli & 95.71 & 14.17 & 0.05 \\
& Page & 94.10 & 19.67 & 0.06 \\
& Verma & 95.66 & 13.93 & 0.05 \\
\hline $3^{\text {rd }}$ & Diffusion approximation & 97.25 & 11.01 & 0.04 \\
& Two-term & 97.40 & 10.86 & 0.04 \\
& Henderson and Pabis & 94.23 & 24.27 & 0.06 \\
& Logarithmic & 97.38 & 11.33 & 0.04 \\
& Midilli & 97.25 & 11.87 & 0.04 \\
& Page & 95.85 & 17.07 & 0.05 \\
& Verma & 97.25 & 11.01 & 0.04 \\
\hline
\end{tabular}

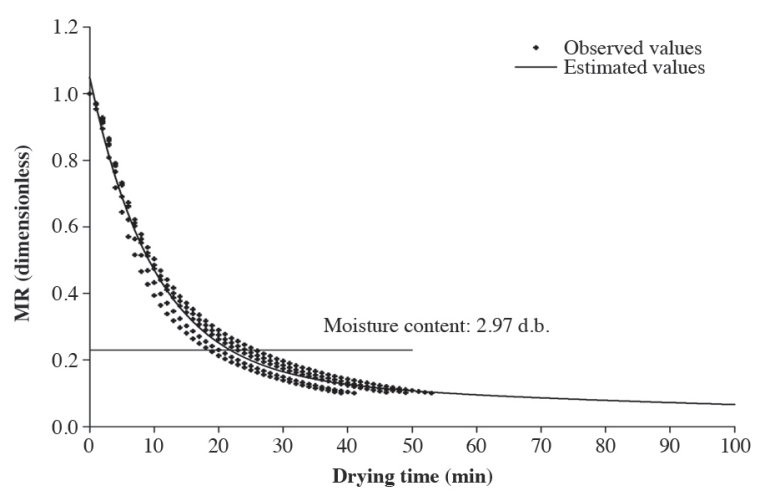

Figure 1. Observed and estimated moisture ratio (MR) values by the twoterm model during drying of tomato fruits at $60^{\circ} \mathrm{C}$ at maturity stage 1 .

moisture content is defined at this point. This parameter divides the drying curve into two parts: before this point, it can be inferred that there is a constant falling rate period in which the velocities of moisture removal at the periphery and moisture replacement from the center to the periphery are considered to be equal; after this point of critical moisture content, a decrease in the moisture ratio with lower velocity is observed in which moisture replacement previously observed cannot supply the removal of moisture by infrared drying at the same velocity.

By analyzing the linearity of experimental data, a critical moisture content of $2.97 \mathrm{~kg}_{\mathrm{w}} \mathrm{kg}_{\mathrm{dm}}{ }^{-1}$ was found for tomato dehydration; this corroborates Brooker et al. (1992), who stated that the critical moisture content for the dehydration of biological products presenting a high initial moisture content ranges from 2.33 to $3.00 \mathrm{~kg}_{\mathrm{w}} \mathrm{kg}_{\mathrm{dm}}{ }^{-1}$.

Figure 2 reports drying rate vs. drying time of tomato fruits dried at $60{ }^{\circ} \mathrm{C}$. It can be observed in Figure 2 that there is an initial period in which the drying rate reaches its maximum value (approximately $1.05 \mathrm{~kg}_{\mathrm{w}} \mathrm{kg}_{\mathrm{dm}}{ }^{-1}$, about $3 \mathrm{~min}$ ). The product is being heated during this period of time. A decrease follows this increase. According to Celma et al. (2009), the initial evaporation occurs on the sample surface. However, this fact becomes less important over time. Therefore, moisture diffusion becomes the

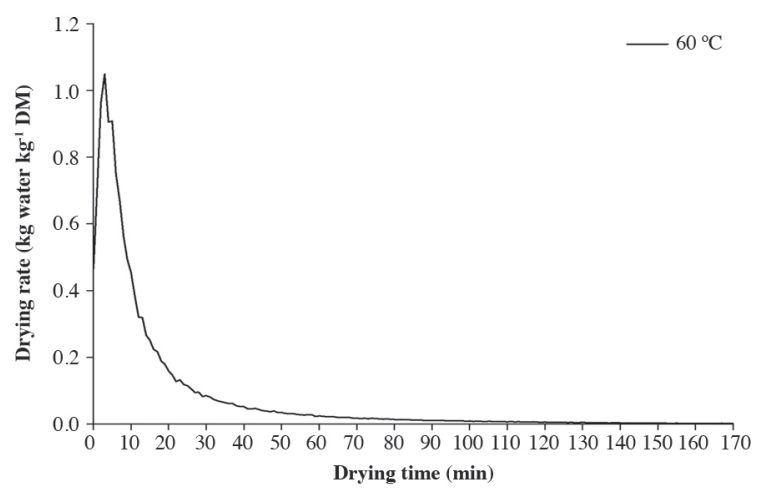

Figure 2. Drying rate values versus drying time at $60^{\circ} \mathrm{C}$ of tomato fruits at maturity stage 1 . 
main factor affecting the drying rate. This trend was also observed for other agricultural products, such as okra (Abelmoschus esculentus (L.) Moench; Doymaz, 2005b) and olive cake (Akgun and Doymaz, 2005).

\section{Diffusion}

For long dehydration periods $(\mathrm{MR}<0.6)$, the diffusion equation can be simplified by a one-term series (Senadeera et al., 2003). Therefore, assuming that $D_{e f}$ is independent of moisture content, Equation [5] can be rewritten as follows:

$$
\ln \mathrm{MR}=\ln \frac{8}{\pi^{2}}-\frac{\pi^{2} D_{e f}}{4 L^{2}}
$$

The effective diffusion coefficient can thus be calculated by replacing the experimental data in Equation [6]. The effective diffusion coefficient is determined by plotting $\ln$ MR vs. drying time, in which the angular coefficient of the linear regression is $\pi^{2} \mathrm{D}_{\mathrm{ef}} / 4 \mathrm{~L}^{2}$.

According to Karathanos et al. (1990), the effective diffusion coefficient of biological materials characterizes the transport of intrinsic mass in the form of water molecules, including molecular diffusion, liquid diffusion, gaseous diffusion, hydrodynamic flow, and other mechanisms. Values of $D_{e f}$ for tomato fruits dried by infrared at maturity stages 1,2 , and 3 were $3.33,2.78$, and $3.05 \times 10^{-7} \mathrm{~m}^{2} \mathrm{~s}^{-1}$, respectively.

Figure 3 shows the plotting of $\ln$ MR $v s$. drying time of tomato fruits at maturity stage 1 . Although the relationship between MR and drying time exhibited a high determination coefficient $\left(\mathrm{R}^{2}=97.99 \%\right)$, it can be observed in Figure 3 that there is a nonlinear tendency of this relationship in the final stage of drying. Celma et al. (2009) reported that the effective diffusion coefficient depends on moisture content when this nonlinearity is observed. These authors reported a relationship between $D_{e f}$ and moisture content represented by Equations [8] and [9]:

$$
\begin{gathered}
F_{0=}=-0.0851-0.4052 \ln M R \\
D_{e f}=\frac{F_{0} L^{2}}{t}
\end{gathered}
$$

where $\mathrm{F}_{0}$ is the Fourier number, dimensionless.

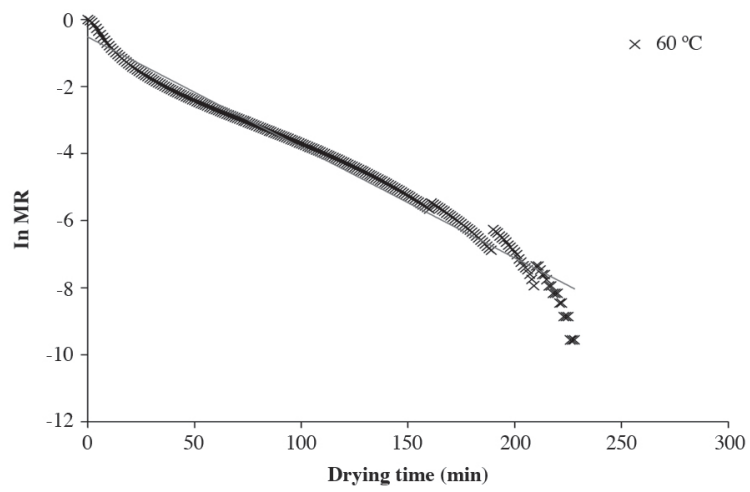

Figure 3. Plotting of In moisture ratio (MR) versus drying time of tomato fruits at maturity stage 1 .
Values were found by this method for the effective diffusion coefficient of $3.75,3.42$, and $3.80 \times 10^{-7} \mathrm{~m}^{2} \mathrm{~s}^{-1}$ at maturity stages 1,2 , and 3 , respectively. The values of these two methods were different and the ANSYS 5.3 (ANSYS, Canonsburg, Pennsylvania, USA) software system was used to detect which method showed the lowest error using the finite element method.

The finite element method (FEM), with its optimization routines, has been recently applied because it is easy to use for complex models and geometries (Gastón et al., 2002). This methodology was used to determine the effective diffusion coefficient of wheat with spherical and ellipsoidal geometries (Gastón et al., 2002); to determine $\mathrm{D}_{\text {ef }}$ values of different apple tissues (Veraverbeke et al., 2003); and to obtain $D_{\text {ef }}$ values during the soaking of rice by considering the expansion feature (Bakalis et al., 2009). Therefore, $D_{\text {ef }}$ values were found by using the two abovementioned methods and a geometry representing the shape of tomato samples.

Moisture transfer within tomato fruit was close to the liquid diffusion theory without generating water inside the control volume and is represented by Equation [10]. The initial condition is stated by Equation [11] by considering that water distribution at the beginning of the process is homogeneous. The boundary condition is represented by Equation [12] by considering the water vapor mass equilibrium between the product and the drying air:

$$
\begin{gathered}
\frac{\delta U_{t}^{*}}{\delta t}=D_{e f} \nabla^{2} U_{t}^{*} \\
U_{t}^{*}(t=0)=U_{i}^{*} \ln \Omega \\
U_{t}^{*}=U_{e}^{*} \ln \Gamma
\end{gathered}
$$

where $\Omega$ is the control volume and $\Gamma$ is the contour surface.

The equilibrium moisture content was calculated by the two-term equation. The geometry of the product was approximated to a sphere with an equivalent diameter of $70.55 \mathrm{~mm}$. This diameter was calculated based on the mean of characteristic dimensions obtained with a 0.01 $\mathrm{mm}$ precision digital caliper. The analysis was carried out with a $45^{\circ}$ angle semi-circle because of geometric symmetry.

A mesh with quadrangular elements and axis symmetry at the surface control was created. Geometry, mesh generation, and model implementation were carried out with the ANSYS 5.3 software system. Simulation results were compared with experimental data in each effective diffusion coefficient. The $D_{\text {ef }}$ values were selected with the least square sum of deviations (Equation [13]) between experimental and simulated data.

$$
R S D=\sum_{j=1}^{n}\left(Y_{j}-\hat{Y}_{j}\right)^{2}
$$

where RSD is the least square sum of deviations; $Y_{j}$ is the observed value; $\hat{Y}_{j}$ is the average value predicted by the model; and $n$ is the number of observed values.

Table 3 shows the values of the effective diffusion coefficient at each tomato maturity stage and the values of 
Table 3. Values for effective diffusion coefficients $\left(D_{\mathrm{ef}}\right)$ and least square sum of deviations (RSD) at each maturity stage of tomatoes obtained with different methods.

\begin{tabular}{lcc}
\hline $\begin{array}{l}\text { Maturity } \\
\text { stage }\end{array}$ & $\mathrm{D}_{\mathrm{ef}}\left(\times 10^{-7} \mathrm{~m}^{2} \mathrm{~s}^{-1}\right)$ & RSD (decimal d.b.) \\
\hline 1 & 3.33 & 0.0138 \\
& 3.75 & 0.0152 \\
2 & 2.78 & 0.0162 \\
& 3.42 & 0.0197 \\
3 & 3.05 & 0.0136 \\
& 3.80 & 0.0129 \\
\hline
\end{tabular}

RSD obtained for each method. The RSD values ranged from 0.0129 to 0.0197 moisture content d.b. Despite these low values none of the methods were able to effectively predict the drying curve (Figure 4). Therefore, an optimization procedure of $D_{e f}$ values was simulated with the ANSYS 5.3 software system. The $D_{e f}$ value was 1.00 $\times 10^{-7} \mathrm{~m}^{2} \mathrm{~s}^{-1}(\mathrm{RSD}=0.0009$ d.b. $)$.

Table 4 shows a wide variation among products and among cultivars of the same product. This trend is probably due to differences in the chemical composition, physical structure, and geometry of the products; these values can vary with boundary conditions, drying methods, and prediction methods of $D_{e f}$ values (Campos et al., 2009; Goneli et al., 2009; Corrêa et al., 2010c).

\section{Mass transfer coefficients}

The global coefficient of heat transfer $\left(h_{c}\right)$ was 12.45 $\mathrm{W} \mathrm{m}{ }^{-2} \mathrm{~K}^{-1}$ and the global coefficient of mass transfer $\left(h_{m}\right) 0.0105 \mathrm{~m} \mathrm{~s}^{-1}$. The values of $h_{m}$ in the present work corroborate the values reported by Touré and KibanguNkembo (2004), who found $0.00974 \mathrm{~m} \mathrm{~s}^{-1}$ for natural dehydration of mango fruits with solar energy, 0.00475

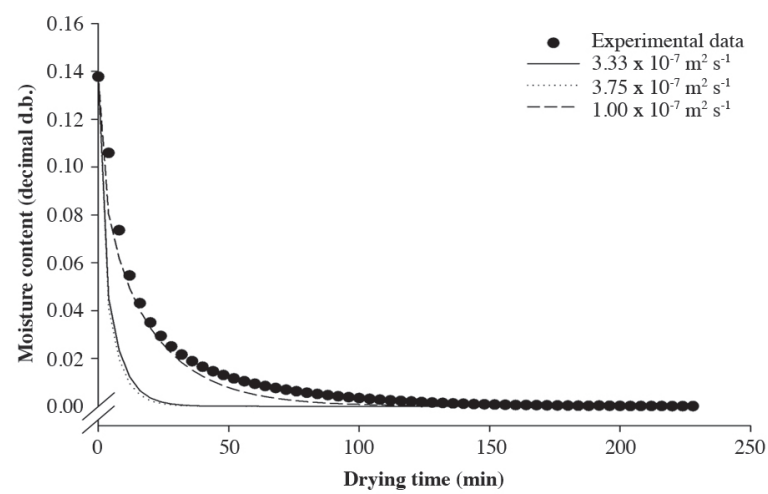

Figure 4. Moisture content variation of tomato fruits dried at $60{ }^{\circ} \mathrm{C}$ at maturity stage 1 as a function of different values of effective diffusion coefficient.

Table 4. Effective diffusion coefficients $\left(D_{e f}\right)$ of different agricultural products.

\begin{tabular}{lcc}
\hline Product & $\mathrm{D}_{\mathrm{ef}}\left(\mathrm{m}^{2} \mathrm{~s}^{-1}\right)$ & Reference \\
\hline Coffee (cv. Catuaí Vermelho) & 2.145 to $2.702 \times 10^{-11}$ & Campos et al. $(2009)$ \\
Coffee (cv. Catuaí Amarelo) & $5.98 \times 10^{-11}$ & Corrêa et al. $(2010 \mathrm{c})$ \\
Tomato by-products & 0.1147 to $9.078 \times 10^{-9}$ & Celma et al. (2009) \\
Grape & 0.5 to $1.0 \times 10^{-9}$ & Çağlar et al. (2009) \\
Onion & $1.0 \times 10^{-8}$ & Mota et al. $(2010)$ \\
Tomato (cv. Santa Cruz) & $1.0 \times 10^{-7}$ & Present work \\
\hline
\end{tabular}

$\mathrm{m} \mathrm{s}^{-1}$ for cassava roots, and 0.00876 and $0.00943 \mathrm{~m} \mathrm{~s}^{-1}$ for two banana cultivars, respectively. Furthermore, the values of $h_{c}$ were expected since, according to Bird et al. (2004), the values of the global coefficient of heat transfer for free convection is between 3 and $20 \mathrm{~W} \mathrm{~m}^{-2} \mathrm{~K}^{-1}$.

\section{CONCLUSIONS}

Dehydration kinetics by infrared drying of tomato slices can be similar to the theoretical studies on heat and mass transfer mechanisms. The values found for the global coefficient of heat and mass transfer were $12.45 \mathrm{~W} \mathrm{~m}^{-2}$ $\mathrm{K}^{-1}$ and $0.0105 \mathrm{~m} \mathrm{~s}^{-1}$, respectively. An effective diffusion coefficient of $1.00 \times 10^{-7} \mathrm{~m}^{2} \mathrm{~s}^{-1}$ was found through an optimization procedure using the finite element method. The two-term model was the best to represent the tomato dehydration process, and the critical moisture content for tomato dehydration was $2.97 \mathrm{~kg}_{\mathrm{w}} \mathrm{kg}_{\mathrm{dm}}{ }^{-1}$. The drying rate reached its maximum value $\left(1.05 \mathrm{~kg}_{\mathrm{w}} \mathrm{kg}_{\mathrm{dm}^{-1}}{ }^{-1}\right)$ at $3 \mathrm{~min}$ of dehydration.

\section{ACKNOWLEDGEMENTS}

The authors thank FAPEMIG and CNPq for funding, which was indispensable to carry out this work.

Secado de tomate por infrarrojo: modelación y algunos coeficientes del proceso de deshidratación. La deshidratación por infrarrojo es más ventajosa que el sistema convectivo, en condiciones similares, y el estudio de este proceso es importante para el desarrollo de equipos y procedimientos. Por tanto, el presente trabajo tuvo como objetivo el estudio del proceso de deshidratación en tres diferentes estados de maduración de rebanadas de tomate (Solanum lycopersicum L.) por medio del secado por infrarrojo, usando dos métodos: aproximación del período constante de deshidratación a la teoría de la transferencia de calor y masa para el termómetro de bulbo húmedo; y al período decreciente de la deshidratación a la teoría de difusión de líquidos. Se utilizaron frutos de tomate cv. Santa Cruz. Tres estados de maduración fueron obtenidos: verde (estado 1), naranja (estado 2) y rojo (estado 3). Modelos matemáticos usualmente utilizados para representar el secado de productos agrícolas fueron ajustados a los datos experimentales del secado de tomate. El coeficiente de difusión efectivo fue obtenido por medio del ajuste del modelo matemático de difusión líquida a los datos experimentales del período decreciente de deshidratación. El modelo Dos Términos representó mejor el proceso del secado de rebanadas de tomate. La humedad crítica para la deshidratación de tomate fue $2.97 \mathrm{~kg}_{\mathrm{w}} \mathrm{kg}_{\mathrm{dm}}{ }^{-1}$. Existe un período inicial de deshidratación en que la tasa de secado alcanzó el máximo (aproximadamente $1.05 \mathrm{~kg}_{\mathrm{w}} \mathrm{kg}_{\mathrm{dm}}{ }^{-1}$, alrededor de $3 \mathrm{~min}$ ). Tres diferentes métodos fueron utilizados para obtener los valores del coeficiente efectivo de difusión, incluyendo el 
método de elementos finitos, en que presentó los menores valores de la suma de desviaciones mínimas al cuadrado, $1.00 \times 10^{-7} \mathrm{~m}^{2} \mathrm{~s}^{-1}$. El coeficiente global de transferencia de calor fue $12.45 \mathrm{~W} \mathrm{~m}^{-2} \mathrm{~K}^{-1}$, y el coeficiente global de transferencia de masa fue $0.0105 \mathrm{~m} \mathrm{~s}^{-1}$.

Palabras clave: humedad crítica, difusión, método de elementos finitos, transferencia de calor y masa, modelación matemática, Solanum lycopersicum.

\section{LITERATURE CITED}

Akgun, N.A., and I. Doymaz. 2005. Modelling of olive cake thinlayer drying process. Journal of Food Engineering 68:455-461.

Bakalis, S., A. Kyritsi, V.T. Karathanos, and S. Yanniotis. 2009. Modeling of rice hydration using finite elements. Journal of Food Engineering 94:321-325.

Bird, R.B., W.E. Stewart, and E.N. Lightfoot. 2004. Fenômenos de transporte. $2^{\mathrm{a}}$ ed. 838 p. LTC Rio de Janeiro, Rio de Janeiro, Brazil.

Brooker, D.B., F.W. Bakker-Arkema, and C.W. Hall.1992. Drying and storage of grains and oilseeds. The AVI Publishing Company, Westport, Connecticut, USA.

Çağlar, A., I.T. Toğrul, and H. Toğrul. 2009. Moisture and thermal diffusivity of seedless grape under infrared drying. Food and Bioproduct Process 87:292-300.

Campos, S.C., P.C. Corrêa, F.M. Botelho, B.L. Nogueira, G.H.H. Oliveira, and A.A. Paixão. 2009. Avaliação da secagem dos grãos de café de diferentes etapas do processamento via úmida. Revista Brasileira de Armazenamento. Especial Café. p. 88-98.

Celma, A.R., F. Cuadros, and F. Lópes-Rodriguez. 2009. Characterisation of industrial tomato by-products from infrared drying process. Food and Bioproducts Processing 89:282-291.

Christensen, C.M., and H.H. Kaufmann. 1974. Storage of cereal grain and their products. p. 158-192. American Association of Cereal Chemists, St. Paul, Minnesota, USA.

Corrêa, P.C., A.L.D. Goneli, P.C. Afonso Júnior, G.H.H. Oliveira, and D.S.M. Valente. 2010b. Moisture sorption isotherms and isosteric heat of sorption of coffee in different processing levels. International Journal of Food Science and Technology 45:20162022.

Corrêa, P.C., G.H.H. Oliveira, F.M. Botelho, A.L.D. Goneli, and F.M. Carvalho. 2010c. Modelagem matemática e determinação das propriedades termodinâmicas do café (Coffea arabica L.) durante o processo de secagem. Revista Ceres 57:595-601.

Corrêa, P.C., G.H.H. Oliveira, A.P.L. Rodrigues, S.C. Campos, and F.M. Botelho. 2010a. Hygroscopic equilibrium and physical properties evaluation affected by parchment presence of coffee grain. Spanish Journalof Agricultural Research 8:694-702.

Diamente, L.M., and P.A. Munro. 1993. Mathematical modelling of the thin layer solar drying of sweet potato slices. Solar Energy 51:271-276.

Doymaz, I. 2005a. Sun drying of figs: An experimental study. Journal of Food Engineering 71:403-407.

Doymaz, I. 2005b. Drying characteristics and kinetics of okra. Journal of Food Engineering 69:275-279.

Gastón, A.L., R.M. Abalone, and S.A. Giner. 2002. Wheat drying kinetics. Diffusivities for sphere and ellipsoid by finite elements. Journal of Food Engineering 52:313-322.

Goneli, A.L.D.,P.C. Corrêa, P.C. Afonso Júnior, and G.H.H. Oliveira. 2009. Cinética de secagem dos grãos de café descascados em camada delgada. Revista Brasileirade Armazenamento. Especial Café. p. 64-73.
Goneli, A.L.D., P.C. Corrêa, G.H.H. Oliveira, and F.M. Botelho. 2010a. Water desorption and thermodynamic properties of okra seeds. Transactions of ASABE 53:191-197.

Goneli, A.L.D., P.C. Corrêa, G.H.H. Oliveira, C.F. Gomes, and F.M. Botelho. 2010b. Water sorption isotherms and thermodynamic properties of pearl millet grain. International Journal of Food Science and Technology 45:828-838.

Hall, C.W. 1980. Drying and storage of agricultural crops. 381 p. AVI Publishing Company, Westport, Connecticut, USA.

Henderson, S.M. 1974. Progress in developing the thin-layer drying equation. Transactions of the ASAE 17:1167-1168.

Henderson, S.M., and S. Pabis. 1961. Grain drying theory. I. Temperature effect on drying coefficient. Journal of Agriculture Engineering Research 6:169-174.

Karathanos, V.T., G. Villalobos, and G.D. Saravacos. 1990. Comparison of two methods of estimation of the effective moisture diffusivity from drying data. Journal of Food Science $55: 218-223$

Midilli, A., H. Kucuk, and Z. Yapar. 2002. A new model for singlelayer drying. Drying Technology 20:1503-1513.

Mota, C.L., C. Luciano, A. Dias, M.J. Barroca, and R.P.F. Guiné. 2010. Convective drying of onion: kinetics and nutritional evaluation. Food and Bioproducts Processing 88:115-123.

Oliveira, G.H.H. 2010. Características físico-químicas do tomate submetido a esforço controlado de compressão. Tesis. Universidade Federal de Viçosa, Viçosa, Minas Gerais, Brazil.

Oliveira, G.H.H., P.C. Corrêa, E.F. Araújo, D.S.M. Valente, and F.M. Botelho. 2010. Desorption isotherms and thermodynamic properties of sweet corn cultivars (Zea mays L.) International Journal of Food Science and Technology 45:546-554.

Sacilik, K.,A.K. Elicin, and G. Unal. 2006. Drying kinetics of Üryani plum in a convective hot-air dryer. Journal of Food Engineering 76:362-368.

Senadeera, W., B.R. Bhandari, G. Young, and B. Wijesinghe. 2003. Influence of shapes of selected vegetable materials on drying kinetics during fluidized bed drying. Journal of Food Engineering 58:277-283

Sharma, G.P., Verma, R.C., and P.B. Pathare. 2005. Thin-layer infrared radiation drying of onion slices. Journal of Food Engineering 67:361-366.

Touré, S., and S. Kibangu-Nkembo. 2004. Comparative study of natural solar drying of cassava, banana and mango. Renewable Energy 29:975-990.

Vasques, A.R., S.L. Bertoli, R.C.S.C. Valle, and J.A.B. Valle. 2006. Avaliação sensorial e determinação de vida-de-prateleira de maçãs desidratadas. Ciência e Tecnologia de Alimentos 26:759-765.

Veraverbeke, E.A., P. Verboven, N. Scheerlinck, M.L. Hoang, and B.M. Nicolaï. 2003. Determination of the diffusion coefficient of tissue, cuticle, cutin and wax of apple. Journal of Food Engineering 58:285-294.

Verma, L.R., R.A. Bucklin, J.B. Endan, and F.T. Wratten. 1985. Effects of drying air parameters on rice dryingmodels. Transaction of ASAE 28:296-301.

Welti-Chanes, J., F. Vergara-Balderas, and D. Bermúdez-Aguirre. 2005. Transport phenomena in food engineering: Basic concepts and advances. Journal of Food Engineering 67:113-128.

Yagcioglu, A., A. Degirmencioglu, and F. Cagatay. 1999. Drying characteristic of laurel leaves under different conditions. p. 565569. In Proceedings of $7^{\text {th }}$ International Congress on Agricultural Mechanization and Energy, Adana, Turkey.

Yaldiz, O., and C. Ertekin. 2001. Thin layer solar drying some different vegetables. Drying Technology 19:583-597. 